\title{
The Customer Value: A Bibliographical Review
}

\author{
Emanuele Iannitto \\ ${ }^{1}$ School of Management, University of Liverpool, Liverpool, United Kingdom \\ Correspondence: Emanuele Iannitto. E-mail: emanuele.iannitto@gmail.com
}

Received: June 24, 2019 Accepted: July 30, 2019 Online Published: August 19, 2019

doi:10.5539/ijms.v11n3p106 URL: https://doi.org/10.5539/ijms.v11n3p106

\begin{abstract}
The perceived customer value is a multi-faceted concept and there is a relationship between the elements that compose an offering and the subjective interpretation of individuals. Within the same product category, different components are more meaningful to customers and have a different influence on shaping their value perception. Identifying the elements of value and the components that are meaningful to customers in a given distribution context helps marketers to focus on the specific characteristics that a value offering should have, in order to be more effective and resonate with the largest number of customers in a target market.
\end{abstract}

Keywords: perceived customer value, offering, customisation, standardisation, competition

\section{Introduction}

Customer value plays a central role in modern marketing. There is a growing interest in researching and analysing the concept of perceived customer value, as marketers are increasingly concerned about designing and implementing effective strategies that can maximise their marketing efforts.

\section{The Concept of Value}

Value is considered as the foundation of all marketing activities and the core of market management (Holbrook, 1994; Anderson \& Narus, 1999). Its multidimensional structure is meaningful for marketers as it enables them to understand how products and services can be designed to appeal to customers in a target market (Gabbott \& Hogg, 1998).

\subsection{Literature and Consensus about the Concept of Value}

Customer value is a concept that is grounded on essence of marketing; this concept has been researched, reviewed, and refined by practitioners and academicians for over 30 years (Gallarza et al., 2011). Surprisingly, literature on customer value, which is a central concept in marketing and determinant for market development and sustainability, is not particularly vast, especially when it comes to defining it and identifying the characteristics and elements that determine it (Day \& Crask, 2000; Al-Sabbahy et al., 2004; Sparks et al., 2008). Customer value is widely recognised as a topic of great significance in marketing. There are, though, certain fragmentations in research and the definitions of customer value are divergent to the point that there is no univocal and widely accepted definition of it (Wang et al., 2004; Lee et al., 2007; Lin et al., 2005). There is also little consensus about how value is achieved and created (Lepak, Smith, \& Taylor, 2007).

\subsection{Measurability of Value}

Some authors, like Arvidsson (2006), argue that value is hardly identifiable and measurable, others like Mathwick et al. (2001) and Lin et al. (2005) address this problem by providing indices of value that can be reliable and valid. But capturing the depth and the multidimensional facets of the concept of value is complex. Many will probably agree with Parasuraman (1997) who sees the concept of value as a construct of such complexity and richness that developing a standard scale to measure it and capture all of its subtle differences proves challenging.

\subsection{Value as Trade-off Between Benefits and Costs}

In business markets, Anderson and Narus (1998) say that value is the worth of various benefits of technical, economic, service and social nature that customers receive in exchange for the price they pay. The authors consider benefits as net benefits, i.e., inclusive of all the costs the customer incurs in getting those benefits. As a consequence, the customer is more likely to choose an offering if the total perceived value is greater than the next best alternative. Prominent in the literature on customer value is the presence of common elements, such as those 
Eggert and Ulaga (2002) notice. Value is made of multiple components, value is a subjective perception and it relates to a competition set. A wide number of definitions of customer perceived value, in fact, focuses on the trade-off between benefits and sacrifices in a given offering, where benefits are not only represented by the intrinsic value of a product, but also by services, image and sacrifices that are not only monetary, but also refer to time, physical and energy efforts (Telli Yamamoto, 2017). Sacrifices are an extremely relevant aspect of value perception (Zeithaml, 1988; Monroe, 1990). Monroe (1990) argues that a reduction in sacrifices is more effective in enhancing customer value perception than an increase in benefits.

\subsection{Value as a Subjective Construct}

A common viewpoint in literature is to consider value as a construct that is subjectively perceived. Customers belonging to different segments, for example, have different perceptions of value within the same category of products (Kortge \& Okonkowo, 1993; Perkins, 1993). Attempting to consolidate the various positions on customer value, Woodruff (1997, p. 142) defines it as "customer's perceived preference for an evaluation of those product attributes, attribute performances and consequences arising from use that facilitate (or block) achieving the customer's goals and purposes in use situations."

\subsection{Value and Competition}

Prominent in the literature on customer value is the fact that value is relative to the competition. To sustain their competitive advantage, firms must deliver a trade-off between benefits and sacrifices that is better than those offered by available competitors so as to generate and offer better customer value. These positions on customer value are all based on the assumption that value is a cognitive comparison process. Patterson and Spreng (1997) effectively describe the concept as a "cognitive-based construct which captures any benefit-sacrifice discrepancy in much the same way disconfirmation does for variations between expectations and perceived performance". In other words, value is a combination of the relative perceived quality and relative perceived price of an offering. Customers will choose those offerings that show them the highest value. Major academic studies of market strategy have helped confirm that the market leader must offer quality that is significantly better than the competition and product and service attributes considered important by its customers (Patterson \& Spreng, 1997).

\subsection{Value as a Multi-Dimensional Concept}

The view that consumer value is a subjective and cognitive process that relates to a context is in line with Holbrook (2005) and his definition of consumer value as "an interactive relativistic preference experience." He argues that a cognitive process takes place when a subject evaluates a given object. In business, when a customer evaluates a product or a service, there is an interaction between the subject and the object that leads to a comparative process involving preference options. Value is relative to individuals, its perception varies across customers, it's relative to a specific context, and it doesn't reside in a specific element but, rather, in the consumption experience. He also propounds the view that customer value is a multidimensional concept. This is also the view point of Kotler and Keller (2012). Value can be extrinsic when it has "functional, utilitarian, or banausic instrumentality in serving as a means to accomplishing some further purpose, aim, goal, or objective." It can be self-oriented when the meaningful aspects of it appeal to a customer's own sake and his/her own benefits, or it can be active whenever it involves some sort of "manipulation" by the customer, i.e. an interaction as part of the consumption experience (Holbrook, 2005).

\subsection{The Value Triad}

The viewpoints on value are very diverse but all consider value a key concept for understanding customer behaviour. Customers and organisations are constantly engaged in transactions in which customers exchange something they value for something with a greater value (Kotler, 1972; Hunt, 1976). The American Marketing Association (AMA, n.d.) defines marketing as "the activity, set of institutions, and processes for creating, communicating, delivering, and exchanging offerings that have value for customers, clients, partners, and society at large" putting, therefore, value in a central position. A focal point is the concept of value that emerges from Kotler and Keller's (2012) work. Kotler and Keller (2012) recognise marketing as the discipline that has the central role of identifying, creating, communicating, delivering, and monitoring value. They define value as a combination of quality, service and price, i.e., what they call the "customer value triad". All the components of value can be connected to these three macro-elements. This is a central marketing concept that explains how value drives customers' choice through the perception of these tangible and intangible benefits. Value perception can, for example, increase with quality and service, and decrease with price. Understanding, creating and delivering customer value is, in all context, the prerequisite for the formulation of an effective value proposition that is a reflection of the value perception sought by customers in the target market (Rintamäki \& Kirves, 2017). 


\subsection{Value and Offering}

The construct of customer value is considered as the driver of the activities that firms conduct to stimulate the customers' willingness to pay for an offering and a tool that firms can use for maximising their chances of surviving the business competition (Beckmann et al., 2016; Cuadros \& Domínguez, 2014). Firms can, therefore, consider value as the sum of the benefits that can be delivered to customers, developing knowledge of their own market offering and answering the question "why should customers buy from us?" (Anderson \& Narus, 2006; Eggert \& Ulaga, 2002). Value can also unfold as an offering that is made up of all meaningful points of difference that are valuable to customers after having considered all the possible alternatives in the market. This viewpoint enables firms to know better their own offering and the market's next best alternative and answer the question "why should customers choose us over the competitors?" Only another stance on value contemplates, instead, offerings that could capture all the key elements that are meaningful to customers. From a customer's point of view, the perception is generally positive as it shows how firms are tuned into their most important necessities and it develops an insightful knowledge of how own offerings deliver superior value to customers, compared with the next best alternative. It answers the question "What is the most worthwhile aspect for our firm to keep in mind about our offering?" (Anderson \& Narus, 2006). Customers don't usually buy for the sake of buying, but it's their attitude towards a product or a brand that makes them buy, recommend, or repeat the purchase and it depends entirely on their perception of the delivered value and its consistency (Hassan, 2012). Further research in the area of consistency of value may include the work of Osterwalder and Pigneur (2003) who observe value along its life cycle and describe how value elements are created and sustained in different stages. Value is traditionally created by companies (even though, recently, the recent concepts of co-creation which will be analysed later in this chapter, have included customers in) that then develop and improve the offerings.

\subsection{Dynamics of Value}

The fact that customer value belongs to the sphere of subjectivity, allows researchers to say that customer value is an interaction between the characteristics of products and individuals (Holbrook \& Hirschman, 1982) and makes it a dynamic concept that evolves over time (Jaworski \& Kohli, 1993; Naumann, 1995). Also traditional and conservative businesses, can, therefore, be influenced by the new technologies that have the power to transform and reshape the industry and the perception of value but, at the same time, can keep sustaining its value for its specific segment of the market in the long run (Beckmann, Royer, \& Schiavone, 1993).

\subsection{Exclusions}

Some other viewpoint on customer value are not analysed here like the opinions developed in the 1980's and in the 1990's by authors that studied the centrality of perceived value in relation to customer service experiences (Bolton \& Drew, 1991; Cronin \& Taylor, 1992) or considered value as an antecedent of satisfaction, focusing only on value as the driver/input of customer satisfaction (Caruana et al., 2000; McDougall \& Levesque, 2000) rather than a "pre-purchase phenomenon" that leads to post-consumption outcomes (Oliver, 1980).

\section{Components of Value}

One of the main challenges for marketers is to make their value proposition resonate with the largest number of customers in their target markets, identifying the elements of value that are more meaningful to them and making them physical through their offering (Kotler \& Keller, 2012). "One of the richest and most productive areas in research on value involves analysis of its conceptual content that is its components and the relationships among them" (Gallarza et al., 2017, p. 6). Holbrook (1995) gives an important contribution to this topic saying that companies strive to position their brands as close as possible to an ideal point in their chosen market segment where they can provide their customers with the maximum value. This ideal point is a combination of "features, attributes, and benefits" that maximise the chances for marketers to gain a greater competitive advantage. In detail, the author delineates a value conceptualisation that includes elements of economic, social, hedonic, and altruistic nature grouped in specific categories namely, efficiency, excellence, status, esteem, play, aesthetics, ethics, and spirituality. Kaufman (1998), instead, in the attempt to define the principal value elements, asserts that attributes of value can be "wants" if they satisfy the customer's desire to own a product and carry it home; this is also what he calls an "esteem value". They can, instead, be "worth" if they have an "exchange value" and explain how or when the customer will use a product, or "needs" if they have a "utility value" and refer to the performance or the practical characteristics of a product.

A great contribution comes from Almquist, Senior, and Bloch (2016) that, pragmatically, expanded Maslow's hierarchy of needs identifying thirty elements of value derived from "scores of quantitative and qualitative studies" and grouped them into three categories. Functional elements like price and quality stay at the base of the value pyramid. Then they list some emotional value elements like aesthetics or attractiveness and life-changing elements 
like motivation and belonging. At the top of the value hierarchy pyramid, we find a social impacting element, self-trascendence, i.e., the element that can appeal to a select group of people who desire spiritual realisation that could overcome the limits of individuality, as found in charity, for example. Understanding the complex nature of customer value is a challenging task. The difficulties lie in the identification of what is really meaningful to prospective customers and making sure it is unique and deliverable. To compose an effective value offering, value has to be broken down into its most basic elements (Almquist, Senior, \& Bloch, 2016). After their identifications firms should, then, focus on the avenues they can use to bring those elements to the customer.

Customers can evaluate value by a cost/benefit trade-off where value is perceived against asking price (Almquist, Senior, \& Bloch, 2016; Leszinski \& Varn, 1997). It is evident that the elements of value play a determinant role in determining the value perception and it is imperative for marketers to balance the price side of the equation with the other components, including functional and emotional ones. The variables can be many and what is truly meaningful to customer can be difficult to understand (Almquist, Senior, \& Bloch, 2016; Anderson \& Narus, 1998). The perception of the amount and the nature of value of a certain product or service resides in the mind of the customer (Almquist, Senior, \& Bloch, 2016) therefore the right combinations of value elements can enhance such perception and result not only in a purchase decision, but also in increased customer loyalty and a better advocacy of the brand. Elements like quality, variety, design, badge value and also characteristics that make customers save time or avoid hassles, are part of the map constituting the elements used for value creation. Perceived customer value of an offering, according to Gutman (1982), is the set of all the benefits that customers expect from it and its undesired consequences as the result of the buying and consuming experience. Both benefits and undesired consequences are the results of the attributes that compose value. These attributes are the elements of an offering that contribute to creating a composite overall perception of value, each element with its own weight. To portray the customer value concept as the result of the value generated by its attributes, Khalifa (2004) elaborates the "value dynamics model" to reflect on how customers evaluate the total offerings. The model divides the attributes of customer value into five categories: satisfiers, dissatisfiers, exciters, value magnifiers, and value destroyers. The foundations of this model are to be sought in Kano's model (Kano et al., 1984), one of the best-known components model in which three components, or, better, three groups of components of value, namely dissatisfiers, satisfiers, and delighters, determine customer satisfaction. According to Kano's model a competitive product or service is made up of:

- $\quad$ some basic attributes that it must necessarily have otherwise it will leave customers dissatisfied

- $\quad$ some performance attributes that increase the satisfaction of customers

- $\quad$ some attributes that excite customers and add value at a cost that the market can bear

Value elements are attributes that can help organisations to solve business problems, create competitive advantages and understand where and how customers perceive their strengths and weaknesses and, from a general point of view, they are also considered to be anything that impacts on the costs and benefits of an offering. Rintamaki et al. (2007) defined value as "an encapsulation of a strategic management decision on what the company believes its customers value the most and what it can deliver that gives it competitive advantage". They can be tangible or intangible, according to Anderson and Narus (1998) and they recommend marketers to consider as many as possible when they design their offerings to avoid the risk of making them look unfavourable to the next best alternative and undermine the credibility of a project.

The elements of value can have a utilitarian nature when they are perceived as functional benefits, or an emotional nature when they relate to the need for uniqueness and interpersonal differentiation (Merle, Chandon, \& Roux, 2009). The authors assert that understanding the impact of the components of consumer value on the overall value is to be regarded as the major research avenue. The elements of value impact on the overall value perception as they influence the ex-ante evaluative judgment of customers that is a result of the comparative process of benefits and sacrifices associated with a product or a service (Zeithaml, 1988).

\section{Value Co-Creation}

Co-creation and customisation refer to a strategy used by brands and retailers to provide individualised products or services, tailored specifically to their individual customers' needs, an approach that is becoming increasingly popular (Fiore, Lee, \& Kunz, 2004). The personalisation of a product or a service through interaction with the customer makes co-creation a powerful relationship marketing tactic, adds value to the offering and enhances the perception of its value, benefiting both retailers and customers (Wind \& Rangaswamy, 2000). The boundaries between firms and customers are getting progressively blurred with customers that become more active and present, not only in the process of creation, but also in the support, promotion, assessment and improvement of products and services. A growing number of firms are called for more interest in engaging customers in 
co-creation programmes to bring their performances and the perception of customer value to a higher level (Jaakola \& Alexander, 2014; Hoyer et al., 2010; Prahalad \& Ramaswamy, 2004)

Research on customer value has often focused on analysing the relationship between benefits and costs or emphasising the construct of benefits as a combination of cognitive and affective aspects (Gallarza et al., 2011; Holbrook, 1999; Lloyd \& Luk, 2010) showing a more flexible and dynamic approach to the topic. An important link between value perception and co-creation is represented by the studies of Vershofen (1959) who asserts that a product conveys basic and additional benefits to customers. Basic benefits are the ones that are responsible for the perception of a utilitarian/functional value, whereas additional benefits relate to social or psychological aspects that are responsible for the perception of emotional value. Co-creation addresses customers' needs and brings them value effectively. Co-creation also creates a value perception that is the sum of all customers' perceived benefits, both basic and additional (Lai, 1995).

The phenomenon of co-creation generates customer value through the interaction between organisations and customers and the integration of their resources (Prahalad \& Ramaswamy, 2000, 2004; Merle, Chandon, \& Roux, 2009). Value is co-created if and when the customer is able to personalise his/her experience in using a company's product or service (Albinsson et al., 2011). Value co-creation plays a significant role in nowadays markets, especially in the context that this research is investigating, as consumers interact more and more frequently with companies, thanks to faster means of communication and participate more actively in the process of defining and creating value (Albinsson et al., 2011). If value creation was once a systematic operation that took place inside the firms and then transferred to the market, now it is a phenomenon that can also be ascribed to co-creation. Customer empowerment, education and connectedness, are part of the value creation process. Personalisation shifts the locus of value creation outside of firms, because it implies and fosters a dialogue between firm and customers that become a source of value themselves (Prahalad \& Ramaswamy, 2004)

The foundations of the concept of value co-creation lie in the idea that value is not carried by the selling organisation only, but rather engendered by customers that become, de facto, co-creators of value (Ballantyne et al., 2011; Vargo \& Lusch, 2008). Value co-creation is founded on elements such as commitment between sellers and buyers, common goals, communication and shared interests. Value co-creation is not necessarily limited to professional contexts. For example, it occurs also in retail shops, purely B2C environments (Baumann \& Le Meunier-FitzHugh, 2015). Merle, Chandon, and Roux (2008) call this phenomenon "experience personalisation". The process of customisation takes place through the relationship between firms and customers and the interaction and co-creation processes become sources of valorisation and enhancement of value perception. According to Merle, Chandon, and Roux (2008), co-creation creates value and benefits the level of value perception thanks to the effectiveness of the value components of the customised product. It helps customers to solve practical problems (utilitarian function), helps them to be distinguished from others (interpersonal differentiation), helps them to represent themselves better (self-expression), gives pleasure and fun (hedonic function) and stimulates creativity (creative fulfilment) (Prahalad \& Ramaswamy, 2004).

It is crucial to understand how customisation happens in business markets, because of its influences on value perception. Gilmore and Pine (1997) explored the topic of customisation, identifying four approaches to it. Collaborative approach is the dialogue with individual customers to uncover their needs; adaptive approach is the offering of a model that customers can alter; cosmetic customisation is intended as the presentation of different variations of product to different customers; transparent customisation mainly regards commodity products that are customised for customers without letting them know explicitly. The key, according to Gilmore and Pine (1997), is to consider customisation options in their multitude of forms (services, experiences, services) as long as they represent an opportunity to create unique customer value in contrast to the standardised customer value delivered by monolithic firms.

Now more than ever, marketers are focused on identifying the most important trends impacting the success of brands in the future. According to Dutzler, Sova, and Kofler (2014), the focus on the customer is a key factor in generating customer value in the fashion/apparel business, and it's achievable only by knowing customers better and engaging with them at all levels. The perceived value can vary, not only in relation to the expected elements of value, but also in relation to the level of customisation of products and services. Also, consumers are increasingly changing their buying behaviours and channel preferences, primarily by moving online. Brands that are poorly differentiated or with a broad positioning, do not have a specific profile and struggle to maintain their relevance to customers. Dutzler, Sova, and Kofler (2014) say that the value perception is higher if brands can satisfy specific needs of the contemporary customer. They sum them up in "know me, engage me, make it easy for me, wow me, and make it work for me". Value perception, therefore, is enhanced with tailored and specific selections of products and services, the direct interaction and dialogue with customers, help of new technologies that speed up 
and make the purchasing process easier, new shop experience and operational excellence.

\section{Value Co-Creation: Customisation and Standardisation}

Existing research theory also suggests that customers contribute to their own perceptions of value, a concept known as value co-creation. Value co-creation is something which can be exceptionally useful in terms of knowledge for organisations and retailers and also a means of forging a very strong bond with consumers if they perceive that their ideas are listened to and incorporated. Customer customisation is indeed not novel, Gilmore and Pine (1997) discussed the idea extensively more than 20 years ago, recognising that organisations that engage in constructive dialogue with their customers as to the perceived value of products and services are in a position to outstrip their competitors as they can provide features and benefits which customers actually want to see and are willing to pay for, as well as considering such attributes to be valuable and therefore attracting a price premium. There are, from a manufacturing perspective and a marketing perspective, distinctions between adaptive, cosmetic, and transparent customisation as suggested by Gilmore and Pine (1997).

Thus, on balance, it can be suggested that there is further support for established theories such as those proposed by Anderson and Narus (2006), Kotler and Keller (2012), and also Almquist et al. (2016) in that it is vitally important to understand precisely what it is that customers place value upon and how they interpret value, as this will have a notable impact on the level of customisation and standardisation.

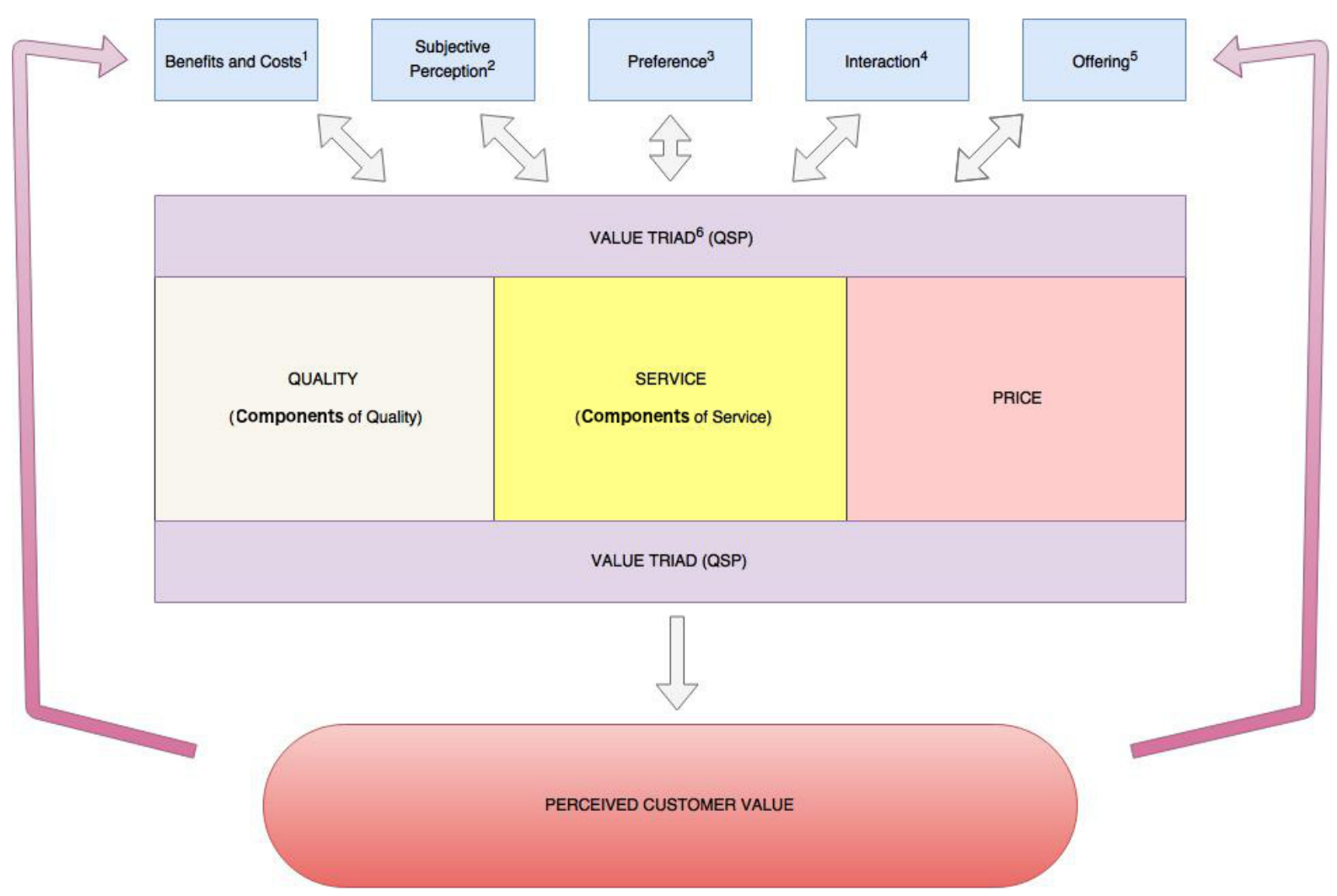

Figure 1. Theoretical framework

Note. 1) Anderson and Narus, 1998; Telli Yamamoto, 2017
2) Kortge and Okonkowo, 1993; Perkins, 1993
3) Woodruff, 1997
4) Holbrook, 2005
5) Anderson and Narus, 2006
6) Kotler and Keller, 2012.

The theoretical framework illustrates the cyclic process of the perception of customer value. Customer value can be described through the three macro-elements of the value triad (Kotler \& Keller, 2012), namely quality, service and price. They are created through cognitive-affective processes and influence the perceived value. The process is 
cyclic as the perception of customer value, then, has an influence and impacts the generation of customer value (Prahalad \& Ramaswamy, 2000, 2004; Merle, Chandon, \& Roux, 2009).

\section{Customer Perception of Value}

It is recognised extensively in literature, that customer perceptions of value are a multifaceted concept depending on many factors, some of which are within the control of organisations or retailers, and some of which are not. For example, Moller and Torronen (2003) suggest that value in the mind of the consumer is comprised of core value (also referred to by some as antecedents of value based on previous experience) and added value, i.e., what a customer perceives as getting over and above the basic item and future potential value. Core value, being a defined construct, is easier to clearly identify and measure as it is provided by the organisation, and is largely objective making it easier to measure, but as the illustration in this research demonstrated, great caution should be advised in assuming that all customers consider the same aspects to be valuable in the same way. This is something already identified by Anderson and Narus (2006), who considered multiple perspectives of value from a customer viewpoint. They demonstrated that a customer can identify or frame value in three different ways, and there is not always the possibility of an organisation knowing which it is that customers have adopted, or even whether their interpretation of value remains constant.

Finally, returning to the work of Anderson and Narus (2006), their final interpretation of value 'reasoning focus', implies that customers have a high level of cognition and involvement in the generation of value, and their interpretation of the value proposition is one whereby the retailer understands what the customer perceives to be value and articulates this either in words or actions. On balance, therefore, customer perception of value depends very much upon the individual customer, and the circumstances in which they find themselves. This reminds us that context is vital when attempting to frame an understanding of value from a customer perspective.

\section{The Discrete and Combined Elements of Value}

Having determined with a reasonable measure of certainty that different customers of different categories perceive value in different ways, attention is then directed towards the constructs of value and the role of the customer in value co-creation. Kotler and Keller (2012) have conducted extensive research and confirm that the value triad of quality, service and price is a generalisable interpretation which can be found across product and service categories and boundaries, and also across geographical and cultural interpretations. Kotler and Keller (2012) determine, quite simply, that it is a combination of these elements which constitute the key decision-making factor in terms of perceptions of customer value, and subsequent interpretations and intent to purchase. The customer decision-making process is one which has been subject to a great deal of attention, with various interpretations suggesting a linear decision-making process and other contributors suggesting that this is a simplistic interpretation and there are many means of bypassing this process on the basis of previous experience or recommendation. Much like the construct of value which varies according to differing interpretations of what constitutes value, and also context, it is not unreasonable to assume that a perception of value in some form feeds into the ultimate decision-making process. The question of what constitutes value, however, varies considerably in terms of its composition, that is to say the discrete and combined elements, and also the extent to which the customer is involved in the generation of value themselves, thus linking back to the third interpretation of Anderson and Narus (2006).

Drawing upon the work of Almquist et al., (2016), as a guiding principle, that recognises that there is a distinction between the basic functions of value propositions, as compared to intangible aspects. To expand, functional components such as price and quality, which can be relatively easily quantified, remain as a founding principle of interpretations of value. Indeed, the findings gathered here very much support this interpretation, with price being a consistent benchmark component and quality varying somewhat but certainly demonstrated in tangible output, such as the quality of the cloth or the buttons and individuality of the lining. However, the emotional interpretation of what constitutes service certainly varies a great deal relative to distribution category and context. According to Almquist et al. (2016), interpretations of value at their pinnacle can be loosely associated with the idea of the human hierarchy of needs (a principle proposed by Maslow). IService, therefore, is a relative and emotive construct in the perception of value. Thus, confirming the theory of Almquist et al. (2016), that there is a relationship associated with the triad of consumer value and its constituent components.

\section{Conclusion}

Even with intense relevance of the concept of perceived consumer value and the increased growth of empirical research on this topic, the heterogeneity and fragmentation of the various approaches are evident. However, from the discussion concerning defining consumer value, it is appropriate to conclude that these convergences reflect generalisations about the objective versus the subjective nature of the concept. Consumer value has been defined 
as the cognitive-affective assessment of an exchange relationship that is conducted by one individual at any given stage in the course of a decision to purchase, also considering elements of preferential, comparative and personal judgement that is conditioned by the place, circumstances and time of the evaluation.

\section{References}

Albinsson, P. A., Perera, B., \& Sautter, E. (2011). Assessing Value Co-creation: DART Scale Development and Validation (vol. 22, pp. 458-459). AMA Summer Educator's Conference Proceedings.

Almquist, E., Senior, J., \& Bloch, N. (2016). The 30 Elements of Consumer Value: A Hierarchy. Harvard Business Review. Retrieved from https://hbr.org/2016/09/the-elements-of-value

AMA (n.d.). Marketing Definition. Retrieved from https://www.ama.org/resources/Pages/Dictionary.aspx

Anderson, J. C., \& Narus, J. A. (1998). Business Marketing: Understand What Customers Value. Harvard Business Review. Retrieved from https://hbr.org/1998/11/business-marketing-understand-what-customers-value

Anderson, J. C., \& Narus, J. A. (1999). Business Market Management: Understanding, Creating, and Delivering Value. Prentice Hall, Upper Saddle River, NJ. https://doi.org/10.1108/08858629910272265

Anderson, J. C., \& Narus, J. A. (2006). Customer Value Propositions in Business Markets. Harvard Business Review. Retrieved from https://hbr.org/2006/03/customer-value-propositions-in-business-markets

Arvidsson, A. (2006). Brands: Meaning and Value in Media Culture. USA: Taylor and Francis. https://doi.org/10.4324/9780203640067

Ballantyne, D., Frow, P., Varey, R. J., \& Payne, A. (2011). Value propositions as communication practice: Taking a wider view. Industrial Marketing Management, 40(2), 202-210. https://doi.org/10.1016/j.indmarman.2010.06.032

Baumann, J., \& Le Meunier-FitzHugh, K. (2015). Making value co-creation a reality exploring the co-creative value processes in customer-salesperson interaction. Journal of Marketing Management, 31(3-4), 289-316, https://doi.org/10.1080/0267257X.2014.956137

Beckmann, O. C., Royer, S., \& Schiavone, F. (2016). Old but sexy: Value Creation of old technology-based businesses models. Journal of Business Models, 4(2), 1-21.

Caruana, A., Money, A. H., \& Berthon, P.R. (2000). Service quality and satisfaction-The moderating role of value. European Journal of Marketing, 34(11/12), 1338-1353. https://doi.org/10.1108/03090560010764432

Cronin, J. J., \& Taylor, S. A. (1992). Measuring service quality: a re-examination and extension. Journal of Marketing, 56, 55- 68. https://doi.org/10.1177/002224299205600304

Cuadros, A., \& Domínguez, V. (2014). Customer segmentation model based on value generation for marketing strategies formulation. Estudios Gerenciales, 30, 25-30. https://doi.org/10.1016/j.estger.2014.02.005

Day, E., \& Crask, M. R. (2000). Value assessment: the antecedent of customer satisfaction. Journal of Consumer Satisfaction, Dissatisfaction and Complaining Behavior, 13, 42-50.

Dutzler, H., Sova, A., \& Kofler, W. (2014). Disruption in the fashion industry: Levers to create value in the future. Retrieved from https://www.strategyand.pwc.com/reports/disruption-fashion-industry

Eggert, A., \& Ulaga, W. (2002). Customer perceived value: a substitute for satisfaction in business markets? Journal of Business \& Industrial Marketing, 17(2/3), 107-118 https://doi.org/10.1108/08858620210419754

Fiore, A. M., Lee, S., \& Kunz, G. (2004). Individual differences, motivations, and willingness to use a mass customization option for fashion products. European Journal of Marketing, 38(7), 835-849. https://doi.org/10.1108/03090560410539276

Gabbott, M., \& Hogg, G. (1998). Consumer and Services. Wiley: Chichester.

Gallarza, M., Arteaga, F., Del Chiappa, G., Gil-Saura, I., \& Holbrook, M. (2017). A multidimensional service-value scale based on Holbrook's typology of customer value: Bridging the gap between the concept and its measurement. Journal of Service Management, 28(4), 724-762. https://doi.org/10.1108/JOSM-06-2016-0166

Gallarza, M., Gil-Saura, I., \& Holbrook, M. (2011). The value of value: Further excursions on the meaning and role of customer value. Journal of Consumer Behaviour, 10(4), 179-191. https://doi.org/10.1002/cb.328

Gilmore, J., \& Pine, J. (1997). The Four Faces of Mass Customization. Harvard Business Review. Retrieved from 
https://hbr.org/1997/01/the-four-faces-of-mass-customization

Gutman, J. (1982). A Means-End Chain Model Based on Consumer Categorization Processes. Journal of Marketing, 46(April), 60-72. https://doi.org/10.1177/002224298204600207

Hassan, A. (2012). The Value Proposition Concept in Marketing: How Customers Perceive the Value Delivered by Firms. International Journal of Marketing Studies. Retrieved from http://www.ccsenet.org/journal/index.php/ijms/article/view/17696/11900.

Holbrook, M. B. (1994). The nature of customer value, Service, Quality: New Directions in Theory and Practice (pp. 21-71). Newbury Park, CA: Sage publications.

Holbrook, M. B. (1995). Communications and customer value, presented at the Institute for Marketing Communications and Strategy. American Marketing Association and Graduate School of Business Administration, Baruch College, October 31.

Holbrook, M. B. (1999). Consumer value: A framework for analysis and research (pp. 1-28). London: Routledge.

Holbrook, M. B. (2005). Consumer value. London: Routledge.

Holbrook, M. B., \& Hirschman, E. C. (1982). The experiential aspects of consumption: consumer fantasies, feelings, and fun. Journal of Consumer Research, 9(2), 132-140. https://doi.org/10.1086/208906

Hoyer, W. D., Chandy, R., Dorotic, M., Krafft, M., \& Singh, S. S. (2010). Consumer co-creation in new product development. Journal of Service Research, 13(3), 283-296. https://doi.org/10.1177/1094670510375604

Hunt, S. D. (1976). The nature and scope of marketing. Journal of Marketing, 40(3), 17-28. https://doi.org/10.1177/002224297604000304

Jaworski, B. J., \& Kohli, A. K. (1993). Market orientation: antecedents and consequences. Journal of Marketing, 57(July), 53-70. https://doi.org/10.1177/002224299305700304

Kano, N., Nobuhiku, S., Fumio, T., \& Shinichi, T. (1984). Attractive quality and must-be quality. Journal of the Japanese Society for Quality Control, 14(2), 39-48.

Khalifa, A. S. (2004). Customer value: a review of recent literature and an integrative configuration. Management Decision, 42(5), 645-666. https://doi.org/10.1108/00251740410538497

Kortge, G. D., \& Okonkwo, P. A. (1993). Perceived value approach to pricing. Industrial Marketing Management, 22, 133-140. https://doi.org/10.1016/0019-8501(93)90039-A

Kotler, P. (1972). A generic concept of marketin. Journal of Marketing, 36, 46-54. https://doi.org/10.1177/002224297203600209

Kotler, P., \& Keller, K. (2012). Marketing Management (14th ed.). New York: Pearson.

Lai, A. W. (1995). Consumer values, product benefits and customer value: A consumption behavior approach. Advances in Consumer Research, 22, 381-388.

Lepak, D., Smith, K., \& Taylor, S. (2007). Introduction to Special Topic Forum: Value Creation and Value Capture: A Multilevel Perspective. Academy of Management Review, 32(1), 180. https://doi.org/10.5465/amr.2007.23464011

Leszinski, R., \& Varn, M. (1997). Setting value, not price. McKinsey \& Company. Retrieved from http://www.mckinsey.com/business-functions/marketing-and-sales/our-insights/setting-value-not-price

Lloyd, A. E., \& Luk, S. T. (2010). The devil wears Prada or Zara: A revelation into customer perceived value of luxury and mass fashion brands. Journal of Global Fashion Marketing, 1(3), 129-141. https://doi.org/10.1080/20932685.2010.10593065

Mathwick, C., Malhotra, N., \& Rigdon, E. (2001). Experiential value: conceptualization, measurement, and application in the catalogue and internet shopping environment. Journal of Retailing, 77(1), 3-56. https://doi.org/10.1016/S0022-4359(00)00045-2

McDougall, G. H. G., \& Levesque, T. (2000). Customer satisfaction with services: putting perceived value into the equation. The Journal of Services Marketing, 14(5), 392-410. https://doi.org/10.1108/08876040010340937

Merle, A., Chandon, J., \& Roux, E. (2009). Why Consumers are Wiling to Pay for Mass Customized Products: Dissociating Product and Experiental Value. Research Gate. https://doi.org/10.1142/9789814280280_0011

Moller, K., \& Torronen, P. (2003). Business suppliers'value creation potential: A capability-based analysis. Sciencedirect.com. Retrieved from http://www.sciencedirect.com/science/article/pii/S0019850102002250 
Monroe, K. B. (1990). Pricing. Making Profitable Decisions. New York, NY: McGraw-Hill.

Naumann, E. (1995). Creating Customer Value. The Path to Sustainable Competitive Advantage. Cincinnati, OH: Thomson Executive Press.

Oliver, R. L. (1980). A cognitive model of the antecedents and con- sequences of satisfaction decisions. Journal of Marketing Research, 17, 460-469. https://doi.org/10.1177/002224378001700405

Osterwalder, A., \& Pigneur, Y. (2003). Modelling Value Propositions in E-Business (pp. 429-436). ICEC 03 proceedings of the 5th international conference on Electronic commerce. https://doi.org/10.1145/948005.948061

Parasuraman, A. (1997). Reflections on gaining competitive advantage through customer value. Journal of the Academy of Marketing Science, 25(2), 154-161. https://doi.org/10.1007/BF02894351

Patterson, P., \& Spreng, R. (1997). Modelling the relationship between perceived value, satisfaction and repurchase intentions in a business-to-business service context: an empirical examination. International Journal of Service Industry Management, 8(5), 414-434.

Perkins, W. S. (1993). Measuring customer satisfaction. Industrial Marketing Management, 22, 247-254. https://doi.org/10.1016/0019-8501(93)90012-V

Prahalad, C. K., \& Ramaswamy, V. (2000). Co-opting Customer Competence. Harvard Business Review, 78(1), 79-87.

Prahalad, C. K., \& Ramaswamy, V. (2004). Co - creation experiences: The next practice in value creation. Journal of Interactive Marketing, 18(3), 5-14. https://doi.org/10.1002/dir.20015

Rintamäki, T., \& Kirves, K. (2017). From perceptions to propositions: Profiling customer value across retail contexts. Journal of Retailing and Consumer Services, 37, 159-167. https://doi.org/10.1016/j.jretconser.2016.07.016

Smith, J. A. (2015). Qualitative psychology: A practical guide to research methods. California: Sage.

Sparks, B., Butcher, K., \& Bradley, G. (2008). Dimensions and correlates of consumer value: an application of the timeshare industry. International Journal of Hospitality Management, 27, 98-108. https://doi.org/10.1016/j.ijhm.2007.07.003

Taylor, S. J., Bogdan, R., \& DeVault, M. (2015). Introduction to qualitative research methods: A guidebook and resource. New Jersey: John Wiley \& Sons.

Telli, Y. G. (2017). Understanding Customer Value Concept: Key to Success. Maltepe University. Retrieved from http://Info.Opf.Slu.Cz/Vvr/Akce/Turecko/Pdf/Yamamoto.Pdf

Vargo, S. L., \& Lusch, R. F. (2008). Service-dominant logic: Continuing the evolution. Journal of the Academy of Marketing Science, 36, 1-10. https://doi.org/10.1007/s11747-007-0069-6

Vershofen, W. (1959). Consumption as the core of economic research. Berlin: C. Heymann Verlag.

Wang, Y., Lo, H. P., \& Yang, Y. (2004). An integrated framework for service quality, customer value, satisfaction: evidence from China's telecommunication industry. Information Systems Frontiers, 6(4), 325-340. https://doi.org/10.1023/B:ISFI.0000046375.72726.67

Wind, J., \& Rangaswamy, A. (2000). Customization: The next revolution in mass customization. Cambridge, MA: MSI.

Woodruff, R. B. (1997). Customer Value: The next Source for Competitive Advantage. Journal of The Academy Marketing Science, 25(2), 139-154. https://doi.org/10.1007/BF02894350

Zeithaml, V. (1988). Consumer Perceptions of Price, Quality, and Value: A Means-Ends Model and Synthesis of Evidence. $\quad$ Retrieved from http://areas.kenan-flagler.unc.edu/Marketing/FacultyStaff/zeithaml/Selected\%20Publications/Consumer\%2 0Perceptions\%20of\%20Price,\%20Quality,\%20and\%20Value-\%20A\%20Means-End\%20Model $\% 20$ and\%2 0Snthesis\%20of\%20Evidence.pdf

\section{Copyrights}

Copyright for this article is retained by the author, with first publication rights granted to the journal.

This is an open-access article distributed under the terms and conditions of the Creative Commons Attribution license (http://creativecommons.org/licenses/by/4.0/). 